\title{
Article \\ Arundo donax L. Biomass Production in a Polluted Area: Effects of Two Harvest Timings on Heavy Metals Uptake
}

\author{
Tommaso Danelli 1,2, Alessio Sepulcri ${ }^{2}$, Giacomo Masetti ${ }^{2}$, Federico Colombo ${ }^{2}$, Stefano Sangiorgio ${ }^{2}$, \\ Elena Cassani ${ }^{1,2}$, Simone Anelli ${ }^{3}$, Fabrizio Adani ${ }^{1,2} \mathbb{C}$ and Roberto Pilu ${ }^{1,2, *}$ \\ 1 Gruppo Ricicla Labs-Department of Agricultural and Environmental Sciences-Production, Landscape and \\ Agroenergy, Università Degli Studi di Milano, Via Celoria 2, 20133 Milan, Italy; \\ tommaso.danelli@unimi.it (T.D.); elena.cassani@unimi.it (E.C.); fabrizio.adani@unimi.it (F.A.) \\ 2 Agricultural Genetics Group-Department of Agricultural and Environmental Sciences-Production, \\ Landscape and Agroenergy, Università Degli Studi di Milano, Via Celoria 2, 20133 Milan, Italy; \\ alessio.sepulcri@studenti.unimi.it (A.S.); giacomo.masetti@studenti.unimi.it (G.M.); \\ federico.colombo@unimi.it (F.C.); stefano.sangiorgio@unimi.it (S.S.) \\ 3 ERSAF, Via Pola 12, 20124 Milano, Italy; Simone.Anelli@ersaf.lombardia.it \\ * Correspondence: salvatore.pilu@unimi.it
}

Citation: Danelli, T.; Sepulcri, A.; Masetti, G.; Colombo, F.; Sangiorgio, S.; Cassani, E.; Anelli, S.; Adani, F.; Pilu, R. Arundo donax L. Biomass Production in a Polluted Area: Effects of Two Harvest Timings on Heavy Metals Uptake. Appl. Sci. 2021, 11, 1147. https://doi.org/10.3390/ app11031147

Academic Editor: Wojciech Zgłobicki Received: 24 December 2020

Accepted: 23 January 2021

Published: 27 January 202

Publisher's Note: MDPI stays neutral with regard to jurisdictional claims in published maps and institutional affiliations.

Copyright: (c) 2021 by the authors. Licensee MDPI, Basel, Switzerland. This article is an open access article distributed under the terms and conditions of the Creative Commons Attribution (CC BY) license (https:/ creativecommons.org/licenses/by/ $4.0 /)$

\begin{abstract}
Within the framework of energy biomass production, Arundo donax L. is very promising for its capability to grow on marginal lands with high yields. This potential can be realized in unused polluted areas where the energy production can be coupled with phytoremediation, and harvested biomass represents a resource and a means to remove contaminants from the soil. Two main processes are considered to evaluate $A$. donax L. biomass as an energy crop, determined by the timing of harvest: anaerobic digestion with fresh biomass before winter and combustion (e.g., pyrolysis and gasification) of dry canes in late winter. The aim of this work was to evaluate the use of A. donax L. in an area polluted by heavy metals for phytoextraction and energy production at two different harvest times (October and February). For that purpose, we established in polluted area in northern Italy (Caffaro area, Brescia) an experimental field of A. donax, and included switchgrass (Panicum virgatum L.) and mixed meadow species as controls. The results obtained by ICP-MS analysis performed on harvested biomasses highlighted a differential uptake of heavy metals depending on harvest time. In particular, considering the yield in the third year, A. donax was able to remove from the soil $3.87 \mathrm{~kg} \mathrm{ha}^{-1}$ of $\mathrm{Zn}$, $2.09 \mathrm{~kg} \mathrm{ha}^{-1}$ of $\mathrm{Cu}$ and $0.007 \mathrm{~kg} \mathrm{ha}^{-1}$ of $\mathrm{Cd}$ when harvested in October. Production of A. donax L. for anaerobic digestion or combustion in polluted areas represents a potential solution for both energy production and phytoextraction of heavy metals, in particular $\mathrm{Cu}, \mathrm{Zn}$ and $\mathrm{Cd}$.
\end{abstract}

Keywords: Arundo donax; switchgrass; heavy metals; phytoremediation; harvest time

\section{Introduction}

The ability of giant reed (Arundo donax L.) to grow on marginal lands means that this plant can be cultivated on soils not suitable for traditional purposes. This plant species produces large amounts of biomass in comparison with traditional energy crops [1]; the adaptability of $A$. donax L. makes this plant fitting for marginal agricultural areas unsuitable for conventional agriculture. In fact, yields up to $20 \mathrm{Mg} \mathrm{DM} \mathrm{ha}^{-1}$ of aboveground biomass at the third year in low-fertility sandy soil have been reported, without the need for any agronomic input, such as weed control and irrigation [2].

The interest in giant reeds is growing because of its high biomass yields and low production costs, and also, for its versatility of usage. Giant reed, in fact, finds applications in the production of bioenergy by different means, such as biogas and bioethanol production, biomass combustion [1] and pyrolysis/gasification [3,4]. This is due to the high calorific value of $18.7 \pm 1.2 \mathrm{MJ} \mathrm{kg}^{-1}$ that is comparable with that of other herbaceous grasses, i.e., switchgrass and miscanthus (HHV of $19.1 \mathrm{~kg}^{-1}$ and $18.7 \mathrm{MJ} \mathrm{kg}^{-1}$ respectively), and woody 
biomasses such as poplar (HHV of $19.5 \mathrm{MJ} \mathrm{kg}^{-1}$ ). In a temperate climate, giant reed, miscanthus, switchgrass and poplar can produce 37-38, 15-30, 10-25 and 9-20 Mg DM ha ${ }^{-1}$, respectively [5]; hence, we can deduce that giant reed, potentially, can produce about respectively $40 \%, 52 \%$ and $59 \%$ more energy per hectare in comparison with the other three crops.

However, even when they have similar calorific values, in general the quality of biomasses, ashes and combustion fumes of herbaceous plants, compared to tree species is significantly lower. In fact, herbaceous biomasses are much richer in $\mathrm{N}, \mathrm{Si}, \mathrm{Ca}, \mathrm{K}, \mathrm{Na}$, $\mathrm{Mg}, \mathrm{Al}, \mathrm{S}$ and $\mathrm{Cl}$ compared to woody biomasses, leading to a substantial increase in the amount of ashes (more than 10 times), which are low melting, creating problems in direct combustion due to maintenance problems in the combustion system. Consequently, the emissions of the herbaceous biomasses' combustion are more polluting, being much richer in total dust, $\mathrm{NOx}, \mathrm{HCl}, \mathrm{SO}_{2}$ and $\mathrm{CO}$ compared to woody plants $[4,6,7]$. For these reasons, the optimization of the pyrolysis/gasification process could mitigate the problems of the quality of the emissions and concentrate the heavy metals present in the biomass in the solid fraction $[4,8]$.

Heavy metals, hydrocarbons and dioxins can affect soil ecosystems sufficiently to result in significant losses in soil quality $[9,10]$. As for the soil pollution problem, phosphatecontaining fertilizers are contaminating agro-ecosystems, mainly with cadmium. Other heavy metal sources are refuse dumps and the applications of sewage sludge [11-13] and Bordeaux mixture (a mixture of copper sulfate and lime) within agriculture. Italy is the fifth most populous country in Europe (about 60 million citizens) and it is a highly developed country. Lombardy, in particular, is characterized by both intensive agriculture and by industries and vehicular traffic; all these activities are sources of air, water and soil pollution. In Italy there are about 15,000 potential contaminated sites. Of these, about 3400 have been declared contaminated and 18 are of national interest for a total of about 100,000 ha. About 30 billion $€$ are needed for decontamination. From 2001 to 2012, about 3.6 billion $€$ was mobilized. The Lombardy Region approved a resolution providing an allocation of 41 million $€$ for the period 2013-2015. These funds are provided to municipalities, provinces and ARPA, to perform new remediation or to supplement those works already in progress, allowing work to continue and to complete interventions on at least 16 contaminated sites [13].

Of course, plants cultivated on contaminated soil absorb different metals, some of which are known to be toxic at low concentrations: because plants constitute the basis of the food chain, the quality of the soils is of primary importance [14].

Metals cannot be degraded, and cleanup generally requires their removal from the soil by "dig and dump" which is expensive and inhibits soil fertility, causing negative impacts on the ecosystem. Despite its potential, phytoremediation is yet to become a commercially viable technology because of the cost and the time needed. However, it would be one of the best approaches to remove contamination from the soil, without destroying the soil structure and fertility. In the phytoremediation process, major mechanisms involve the roots and rhizosphere (filtration, degradation) and the whole plant (degradation, volatilization, stabilization, extraction). Hence, the phytoremediation process could be the best technique for the remediation of widespread polluted areas, in particular where metals are present at relatively low concentrations in the surface layers of the soil $[15,16]$. The main approaches proposed for phytoremediation are "chelate-assisted phytoextraction" and "continuous phytoextraction." In the first case the mobility and the uptake of metals in soil are increased by artificial chelates added to soil, in the second case the natural ability of plants to absorb metals is used [17]. Hyperaccumulator plant species could represent a winning solution if they did not still have various limits to their use, such as low biomass production and shallow root systems $[18,19]$. To overcome these limits we will have to create plants capable of hyperaccumulating metals and at the same time producing a large amount of biomass; the removed heavy metals could be recycled from the harvested contaminated plant biomass [20]. Hence, phytoextraction potential is mainly influenced by two factors: 
(i) element concentration in aboveground biomass and (ii) yield of aboveground dry biomass. Several pilot experiments have been performed in recent years using annual and perennial woody plants, showing the potential of this technique [21]. Producing energy from biomass increases considerably the sustainability of phytoremediation action [22] and generates a positive impact due to fossil fuel substitution. Remediation techniques that use soil-plant systems cannot be limited to one decontamination mechanism. Many processes occur simultaneously in every in situ application. In a field trial, different strategies can be adopted to obtain the desired effect on each soil pollutant. Degradation and volatilization through plant stomata of arsenic [23] and cadmium phytoextraction and adsorption on raw leaves [24], for example, can be maximized with the same crop management choices. Plants can have morphological and physiological responses to organic pollutants. Phenantrene, for example, shows high toxicity in maize and leads to water stress symptoms, with higher calcium, phosphorus, magnesium and zinc contents in leaves [25]. Thus, the interfering of some pollutants with transpiration and micro-element balance needs to be taken into account.

Until now, phytoremediation has been limited by the long period of time plants require to reduce contaminant levels $[26,27]$. Optimal plants for phytoremediation should have the following characteristics: (i) high biomass production harvested per year with economic value; (ii) extensive root systems; (iii) tolerance and accumulations of heavy metals in harvestable biomass.

This description resembles the characteristics of giant reed, which is a perennial rhizomatous grass, widely diffused in subtropical and temperate regions; due to its great adaptability and well-documented tolerance to heavy metals contamination, it is considered as one of the most promising energy crops [28].

This species can grow in polluted soil where the concentration of each of $\mathrm{Cd}^{2+}, \mathrm{Cu}^{2+}$,

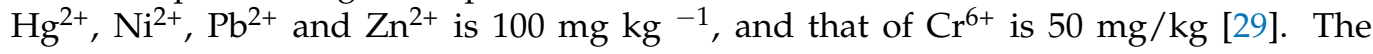
characteristics of high biomass production and the exuberant root system of A. donax $\mathrm{L}$. suggest that it has great potential in remediation of polluted soils.

Cultivating A. donax L. on contaminated lands can contribute to the availability of higher-quality land and limit the food vs. plant-based feedstock controversy. Persistent occupation of the soil by inedible plants is a form of pollution mitigation, an ecological passage and a pool for biodiversity for any urban or suburban area. A positive impact on the environment is generated even at an early stage and in sites where urbanization has left scarcely any solutions for environmental recovery. The use of $A$. donax L. for phytoremediation is well documented in removing $\mathrm{As}, \mathrm{Cd}, \mathrm{Cr}, \mathrm{Fe}, \mathrm{Hg}, \mathrm{Mn}, \mathrm{Ni}, \mathrm{Pb}$ and $\mathrm{Zn}$ and for treating urban wastewater, aqueous solutions from industrial processes and in general wastewater containing organic compounds [1]. Some ex situ experimentation found that there was slightly to no loss in biomass production of $A$. donax L. on polluted soils, and it showed its capability to extract heavy metals in response to their presence in the soil [1]. However, limited growth conditions in ex situ (e.g., pot) experimentation can limit the significance of these studies [30]. For this reason, we established an experimental field of A. donax L., switchgrass (Panicum virgatum L.) and mixed meadow species in an area polluted by heavy metals. The polluted site chosen for this work was located in the Caffaro area (Brescia, North Italy), with an area of 12.5 hectares. This site was previously characterized (by ERSAF Brescia): the concentration values of different heavy metals and dioxins in the surface layers of the soil $(0-40 \mathrm{~cm})$ exceed the values shown in Legislative Decree number 152 of 2006 [27] concerning the remediation of contaminated sites, column " $\mathrm{A}$ " (soil for residential/public green) and for some items, column " $\mathrm{B}$ " (soil for industrial use), (Italy, 2006). The experiment was conducted for 3 years, with the objective of: (a) comparison of the biomass yield; (b) assessing the capacity to accumulate heavy metals in the aboveground biomass; and (c) assessing the best harvesting period to maximize the metals' concentrations in the biomass. 


\section{Materials and Methods}

\subsection{Plant Material}

The three-year experiment described in this study was performed using the selected Ad20 clone from the Italian Arundo donax L. (Ad) collection located in Landriano (PV, Italy, $45^{\circ} 18^{\prime} \mathrm{N}, 9^{\circ} 15^{\prime} \mathrm{E}$ ); sown switchgrass (Pv) var. Alamo; and as control, the mixed meadows (MM) species already present in the area. The A. donax L. clone Ad20 represents a promising genotype for large scale cultivation, due to its production potential and efficient propagation [31-33]. The control MM was constituted by the predominant species Medicago sativa and Chenopodium album. No management of the field had been done for the previous 5 years.

\subsection{Field Establishment}

The experiments described in this study were carried out in a field within the Caffaro area (N 45.5358, E 10.1841). The soil characteristics at the experimental site are reported in Table 1, which includes the contents of 12 heavy metal pollutants resulting from ICP-MS analysis, as described in Section 2.4.

Table 1. Soil characteristics at the experimental site 0-30 cm (March 2017) and soil thresholds for residential/recreational and commercial or industrial use, by Italian norms concerning the remediation of contaminated soils [34].

\begin{tabular}{|c|c|c|c|}
\hline Parameter & Value & $\begin{array}{l}\text { Residential-Recreational } \\
\text { Land Use Threshold }\end{array}$ & $\begin{array}{l}\text { Commercial or Industrial } \\
\text { Land Use Threshold }\end{array}$ \\
\hline Sand $(2-0.05 \mathrm{~mm})(\%)$ & 38.49 & & \\
\hline Silt $(0.05-0.002 \mathrm{~mm})(\%)$ & 49.84 & & \\
\hline Clay $(<0.002 \mathrm{~mm})(\%)$ & 11.66 & & \\
\hline $\mathrm{pH}$ & 7.83 & & \\
\hline Organic matter (Walkley-Black) (\%) & 0.14 & & \\
\hline Total nitrogen (Kjeldahl) $\left(\mathrm{g} \mathrm{kg}^{-1}\right)$ & 1.65 & & \\
\hline Cation Exchange Capacity (meq $100 \mathrm{~g}^{-1}$ ) & 24.77 & & \\
\hline $\mathrm{Al}\left(\mathrm{g} \mathrm{kg}^{-1}\right)$ & $21.40 \pm 0.62$ & -1 & - \\
\hline $\mathrm{Cr}\left(\mathrm{mg} \mathrm{kg}^{-1}\right)$ & $36.04 \pm 8.18$ & 150 & 800 \\
\hline $\operatorname{Mn}\left(\mathrm{mg} \mathrm{kg}^{-1}\right)$ & $805.64 \pm 69.73$ & - & - \\
\hline $\mathrm{Fe}\left(\mathrm{g} \mathrm{kg}^{-1}\right)$ & $23.05 \pm 1.14$ & - & - \\
\hline $\mathrm{Co}\left(\mathrm{mg} \mathrm{kg}^{-1}\right)$ & $12.97 \pm 0.52$ & 20 & 250 \\
\hline $\mathrm{Ni}\left(\mathrm{mg} \mathrm{kg}^{-1}\right)$ & $29.99 \pm 3.10$ & 120 & 500 \\
\hline $\mathrm{Cu}\left(\mathrm{mg} \mathrm{kg}^{-1}\right)$ & $89.38 \pm 25.58$ & 120 & 600 \\
\hline $\mathrm{Zn}\left(\mathrm{mg} \mathrm{kg}^{-1}\right)$ & $183.85 \pm 35.26$ & 150 & 1500 \\
\hline As $\left(\mathrm{mg} \mathrm{kg}^{-1}\right)$ & $32.41 \pm 7.09$ & 20 & 50 \\
\hline $\mathrm{Mo}\left(\mathrm{mg} \mathrm{kg}^{-1}\right)$ & $0.52 \pm 0.12$ & - & - \\
\hline $\mathrm{Cd}\left(\mathrm{mg} \mathrm{kg}^{-1}\right)$ & $0.39 \pm 0.09$ & 2 & 15 \\
\hline $\mathrm{Pb}\left(\mathrm{mg} \mathrm{kg}^{-1}\right)$ & $128.25 \pm 49.03$ & 100 & 1000 \\
\hline
\end{tabular}

${ }^{1}$ Non-regulated values in soils.

The field was established by transplanting $A$. donax plantlets with a density of 2500 plants ha ${ }^{-1}$ or switchgrass with a density of 10,000 plants ha $^{-1}$. The experimental design was a randomized block with three replications of $100 \mathrm{~m}^{2}$. Weed competition was avoided by operating on the surrounding area with a mulching plastic film during the first year and by mowing operations in the second and third years.

Plantlets were irrigated as needed after transplantation to avoid water scarcity in the first year. During the subsequent two years no irrigation, no fertilization and no chemical treatments were done. Every February, after the sampling, the plots were cut down and the aboveground biomass removed.

\subsection{Biomass Sampling}

From each block, biomass coming from $16 \mathrm{~m}^{2}$ was harvested and weighed in October or in February for three harvest seasons during the years 2016-2020. After shredding, 
the dry matter (DM) of biomass was obtained by inserting the samples in pre-weighed aluminum bags which were dried in a forced-air oven at $80^{\circ} \mathrm{C}$ for $72 \mathrm{~h}$. All dried plants were ground with a laboratory mill to $0.5 \mathrm{~mm}$ (Cyclone Sample Mill, Model 3010-019, pbi International, Milan, Italy).

\subsection{ICP-MS Analysis}

Each sample was divided into three subsamples for technical repetitions. The analyses were performed on digested $300 \mathrm{mg}$ of dry matter $\left(65 \% \mathrm{HNO}_{3}\right)$ by a microwave digester system (Anton Paar Multiwave 3000, Austria). Diluted samples were measured by ICP-MS (Varian 820 ICPMS, Agilent, Santa Clara, CA, USA) as reported in [35].

\subsection{Statistical Analysis}

Species (S), year (Y) and harvest time (HT) factors were considered as independent variables, while the three blocks for each treatment represented the random factor. Statistical significance of effects was examined by IBM SPSS version 20 software [36]. The tests used a confidence interval of $95 \%$ and the normal distribution, and homoscedasticity of treatments was assessed by, respectively, the Shapiro-Wilk test under command EXPLORE and the Levene test. To discriminate differences in biomass yield among treatments, a univariate approach was applied, with the command UNIANOVA under satisfied requisites of the analysis of variance. For each block, results of ICP-MS on the three subsamples were aggregated to their mean value. A PCA analysis of heavy metals' biomass concentrations as components was conducted on standardized values for each treatment with PAST version 3.12 software [37]. A multivariate approach to analyze heavy metals' biomass contents was applied by GLM command on SPSS software, with re-sampling of cases by wild residual BOOTSTRAP command with 1100 repetitions, as some treatments did not satisfy the requisites of analysis of variance. Post hoc analysis was performed by Tukey's test and pairwise comparisons were performed by EMMEANS subcommand, using Sidak as the adjustment method.

\section{Results}

\subsection{Biomass Yield}

Considering the production of biomass, the main effects of the factors species (S), year $(Y)$ and their interaction were significant $(p<0.05)$, but no effect was found for the factor harvest time (HT). The mixed meadow (MM) showed, as expected, homogeneous production during the three years of experimentation, with an estimated mean of $13.23 \pm 1.33$ tonnes $\mathrm{DM} \mathrm{ha}^{-1}$ at each harvest. During the first year, A. donax L. (Ad) and switchgrass (Pv) produced less biomass compared to controls, with a mean production of $7.67 \pm 1.66$ tonnes $\mathrm{DM} \mathrm{ha}^{-1}$. In the second year, the biomass yields of both Ad and Pv were statistically larger than the control MM $(p<0.05)$, as can be observed in Figure 1.

$\mathrm{Pv}$ increased its production in the second year with no significant difference compared to the third year, with an estimated biomass yield of $18.35 \pm 1.58$ tons $\mathrm{DM} \mathrm{ha}^{-1}$. Ad had an increase in biomass production in both the second and third years, with biomass yields of, respectively, $27.90 \pm 2.81$ and $33.29 \pm 2.96$ tons $\mathrm{DM} \mathrm{ha}^{-1}$. The homogeneous subgroups are shown in Figure 2. 


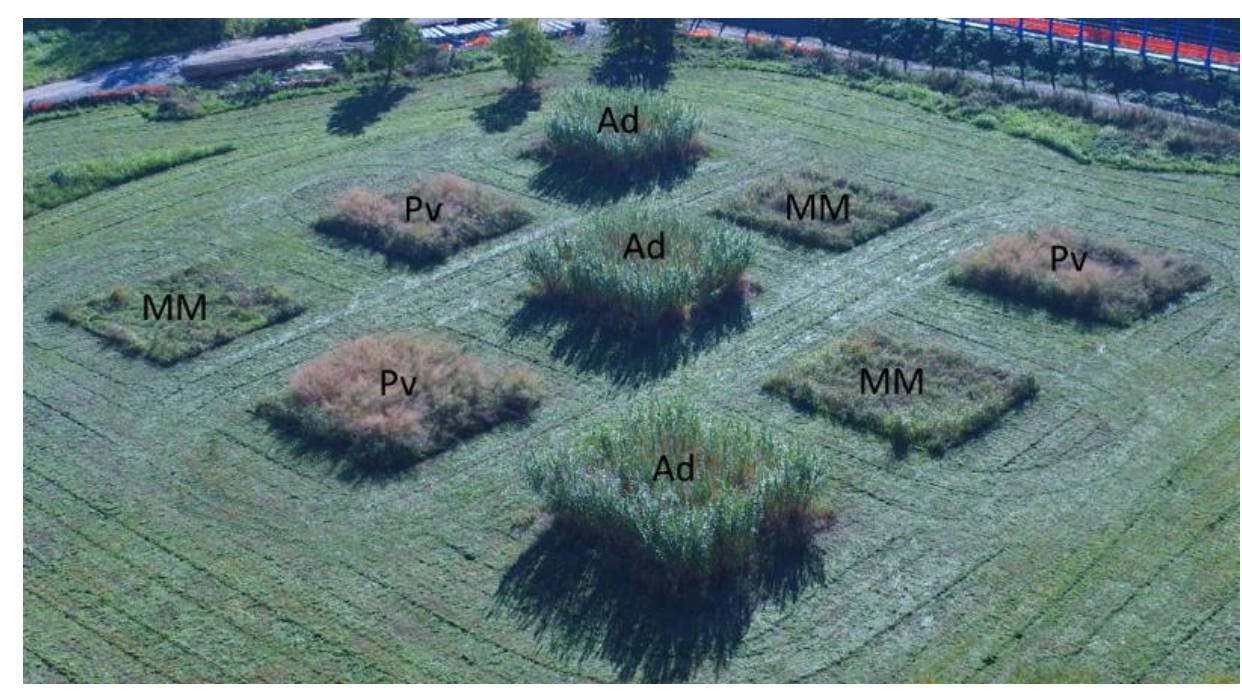

Figure 1. Experimental field photographed from the air during the period of this study. The letters represent the different species used: A. donax (Ad); switchgrass $(\mathrm{Pv})$ and mixed meadow $(\mathrm{MM})$. Each block has the dimensions of $10 \mathrm{~m} \times 10 \mathrm{~m}$ with a distance of $10 \mathrm{~m}$ between the plots. The grass between the plots was regularly mown, to avoid growth of surrounding weeds.

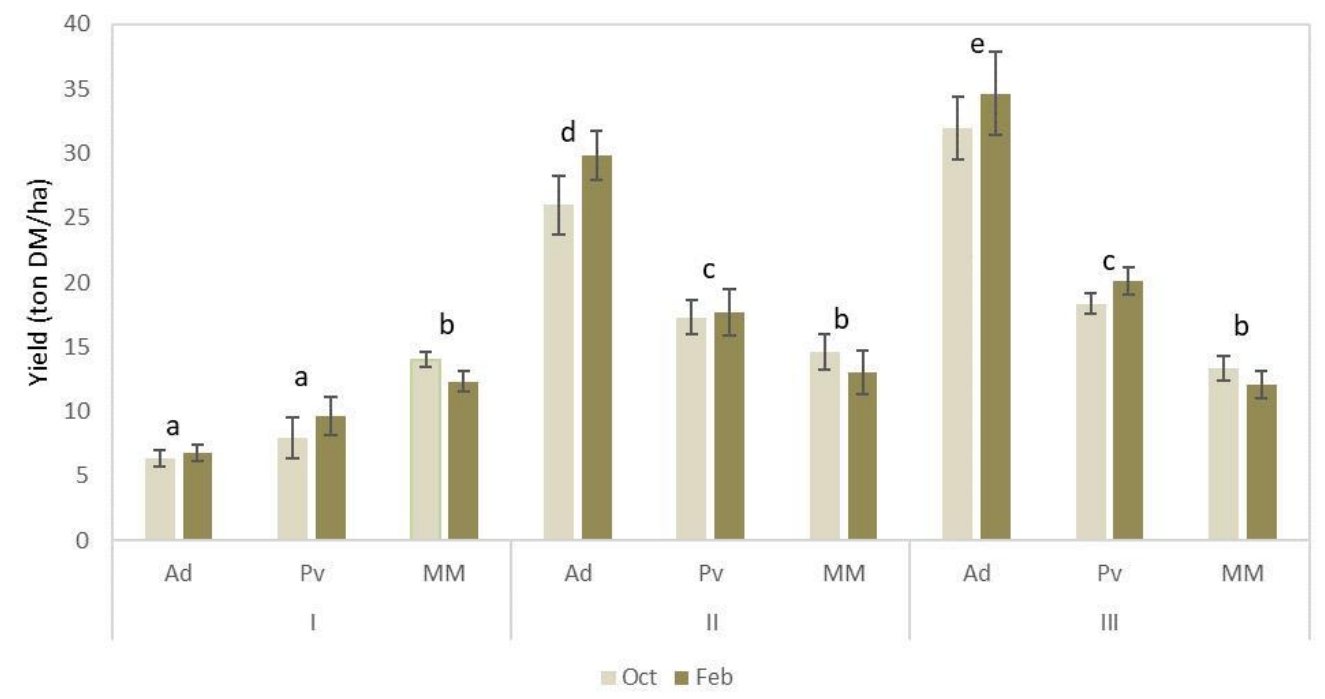

Figure 2. Estimated biomass yield of the treatments, each column representing each harvest operation under the different combination of year (I, II and III), species (Arundo-Ad, switchgrass-Pv and mixed meadows-MM) and harvest times (October and February). Error bars represent SD and letters $\mathrm{a}, \mathrm{b}$ and $\mathrm{c}$ label statistically homogeneous subgroups $(p<0.05)$.

\subsection{Heavy Metals in Harvested Biomass}

ICP-MS results for the three subsamples (randomized blocks) for each treatment regarding $\mathrm{Al}, \mathrm{Cr}, \mathrm{Mn}, \mathrm{Fe}, \mathrm{Co}, \mathrm{Ni}, \mathrm{Cu}, \mathrm{Zn}, \mathrm{As}, \mathrm{Mo}, \mathrm{Cd}$ and $\mathrm{Pb}$ showed about $1 \%$ of outlier data. The normality of distribution of the different combinations of factors was confirmed for $95 \%$ of treatments, but homoscedasticity was not confirmed by the vast majority of samples $(\alpha=0.05)$. Table 2 summarizes the mean values and standard deviations for each heavy metal among the different samples. 


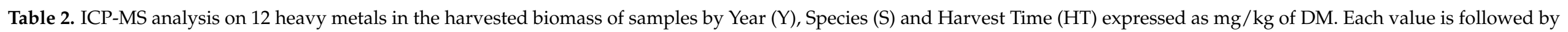
its SD.

\begin{tabular}{|c|c|c|c|c|c|c|c|c|c|c|c|c|c|c|}
\hline Y & $\mathbf{S}$ & HT & $\mathrm{Pb}$ & $\mathrm{Cd}$ & Mo & As & Zn & $\mathrm{Cu}$ & $\mathbf{N i}$ & Co & $\mathrm{Fe}$ & Mn & $\mathrm{Cr}$ & Al \\
\hline \multirow{6}{*}{ I } & \multirow{2}{*}{ Ad } & October & $0.43 \pm 0.1$ & $0.06 \pm 0.01$ & $1.39 \pm 0.22$ & $0.06 \pm 0.03$ & $76.05 \pm 23.24$ & $8.66 \pm 0.31$ & $0.02 \pm 0$ & $0.02 \pm 0.01$ & $56.21 \pm 7.54$ & $62.47 \pm 8.37$ & $1.56 \pm 0.38$ & $12.08 \pm 2.33$ \\
\hline & & February & $0.61 \pm 0.06$ & $0.14 \pm 0.07$ & $2.02 \pm 0.45$ & $0.05 \pm 0.01$ & $39.46 \pm 10.91$ & $8.86 \pm 0.93$ & $0.5 \pm 0.7$ & $0.15 \pm 0.01$ & $90 \pm 6.73$ & $93.91 \pm 20.94$ & $4.96 \pm 0.85$ & $19.26 \pm 11.6$ \\
\hline & \multirow{2}{*}{$\mathrm{Pv}$} & October & $0.31 \pm 0.06$ & $0.04 \pm 0.01$ & $0.99 \pm 0.64$ & $0.04 \pm 0.03$ & $24 \pm 6.23$ & $4.44 \pm 1.12$ & $0.02 \pm 0.01$ & $0.02 \pm 0.02$ & $38.15 \pm 9.61$ & $16.19 \pm 7.4$ & $2.03 \pm 0.08$ & $11.3 \pm 8.15$ \\
\hline & & February & $1.76 \pm 0.56$ & $0.02 \pm 0.01$ & $2.21 \pm 1.94$ & $0.03 \pm 0.01$ & $52.17 \pm 13.61$ & $10.96 \pm 2.85$ & $1.87 \pm 1.13$ & $0.19 \pm 0.04$ & $180.74 \pm 58.9$ & $19.37 \pm 6.22$ & $8.26 \pm 3.37$ & $65.58 \pm 21.78$ \\
\hline & \multirow{2}{*}{ M } & October & $0.41 \pm 0.05$ & $0.02 \pm 0.01$ & $2.72 \pm 0.75$ & $0.02 \pm 0.01$ & $47.21 \pm 24.73$ & $5.05 \pm 2.07$ & $0.02 \pm 0.01$ & $0.03 \pm 0.01$ & $35.97 \pm 20.35$ & $30.2 \pm 7.46$ & $0.88 \pm 0.78$ & $11.85 \pm 14.65$ \\
\hline & & February & $1.34 \pm 1.19$ & $0.03 \pm 0.01$ & $1.6 \pm 1.37$ & $0.05 \pm 0.05$ & $30.7 \pm 6.51$ & $9.52 \pm 5.69$ & $0.24 . \pm 0.39$ & $0.29 \pm 0.36$ & $125.4 \pm 104.8$ & $30.57 \pm 10.86$ & $1.51 \pm 1.4$ & $48.19 \pm 11.01$ \\
\hline \multirow{5}{*}{ II } & Ad & October & $0.12 \pm 0.06$ & $0.02 \pm 0.01$ & $2.09 \pm 0.58$ & $0.18 \pm 0.02$ & $115.1 \pm 100.7$ & $7.4 \pm 1.61$ & $0.8 \pm 0.05$ & $0.05 \pm 0.01$ & $72.91 \pm 35.59$ & $20.68 \pm 2.93$ & $1.8 \pm 0.8$ & $15.42 \pm 7.96$ \\
\hline & \multirow{2}{*}{$\mathrm{Pv}$} & October & $0.3 \pm 0.04$ & $0.21 \pm 0.17$ & $2.57 \pm 1.53$ & $0.2 \pm 0.04$ & $43.76 \pm 13.83$ & $5.71 \pm 1.08$ & $1.06 \pm 0.53$ & $0.05 \pm 0.01$ & $71.26 \pm 6.72$ & $16.07 \pm 10.05$ & $3.39 \pm 0.76$ & $27.17 \pm 7.23$ \\
\hline & & February & $0.61 \pm 0.19$ & $0.03 \pm 0.01$ & $1.95 \pm 1.38$ & $0.31 \pm 0.28$ & $39.65 \pm 11.42$ & $6.04 \pm 1.18$ & $1.14 \pm 0.37$ & $0.05 \pm 0.01$ & $88.71 \pm 22.17$ & $13.14 \pm 3.01$ & $4.38 \pm 1$ & $40.68 \pm 13.73$ \\
\hline & \multirow{2}{*}{$\mathrm{M}$} & October & $0.46 \pm 0.08$ & $0.05 \pm 0.01$ & $4.67 \pm 2.23$ & $0.28 \pm 0.04$ & $62.69 \pm 14$ & $8.58 \pm 1.8$ & $1.03 \pm 0.36$ & $0.07 \pm 0.02$ & $104.17 \pm 10.25$ & $28.07 \pm 14.15$ & $3.49 \pm 1.47$ & $34.79 \pm 1.66$ \\
\hline & & February & $0.84 \pm 0.05$ & $0.03 \pm 0.02$ & $4.49 \pm 3.65$ & $0.24 \pm 0.06$ & $88.6 \pm 26.06$ & $6.19 \pm 1.5$ & $1.13 \pm 0.24$ & $0.12 \pm 0.04$ & $148.72 \pm 22.79$ & $24.08 \pm 7.88$ & $4.24 \pm 0.27$ & $88.29 \pm 24.08$ \\
\hline \multirow{5}{*}{ III } & \multirow{2}{*}{$\mathrm{Ad}$} & October & $0.76 \pm 0.53$ & $0.21 \pm 0.05$ & $2.22 \pm 0.44$ & $0.11 \pm 0.06$ & $121 \pm 110.01$ & $6.55 \pm 1.59$ & $0.81 \pm 0.56$ & $0.16 \pm 0.02$ & $74.07 \pm 39.57$ & $21.71 \pm 4.42$ & $1.48 \pm 0.59$ & $16.26 \pm 11.2$ \\
\hline & & February & $0.48 \pm 0.02$ & $0.11 \pm 0.01$ & $1.58 \pm 0.24$ & $0.07 \pm 0.01$ & $28.51 \pm 2.4$ & $4.94 \pm 0.3$ & $0.74 \pm 0.05$ & $0.1 \pm 0.03$ & $68.99 \pm 16.82$ & $30.06 \pm 3.66$ & $2.56 \pm 0.93$ & $23.85 \pm 8.78$ \\
\hline & $\mathrm{Pv}$ & October & $0.51 \pm 0.23$ & $0.35 \pm 0.18$ & $2.21 \pm 1.33$ & $0.11 \pm 0.01$ & $45.53 \pm 13.41$ & $6.52 \pm 2.27$ & $1.39 \pm 0.58$ & $0.16 \pm 0.03$ & $85.7 \pm 3.2$ & $16.78 \pm 8.38$ & $3.5 \pm 0.92$ & $27.81 \pm 5.16$ \\
\hline & \multirow{2}{*}{$\mathrm{M}$} & October & $0.92 \pm 0.36$ & $0.13 \pm 0.06$ & $4.05 \pm 1.9$ & $0.16 \pm 0.03$ & $67.84 \pm 11.02$ & $9.85 \pm 1.57$ & $0.89 \pm 0.48$ & $0.16 \pm 0.03$ & $125.63 \pm 13.2$ & $30.39 \pm 14.22$ & $3.24 \pm 1.16$ & $32.7 \pm 1.53$ \\
\hline & & February & $1.39 \pm 0.71$ & $0.13 \pm 0.03$ & $4.05 \pm 2.88$ & $0.09 \pm 0.02$ & $94.84 \pm 23.84$ & $6.43 \pm 0.77$ & $1.17 \pm 0.5$ & $0.21 \pm 0.06$ & $162.4 \pm 14.39$ & $25.69 \pm 5.17$ & $3.53 \pm 0.61$ & $88.17 \pm 22.28$ \\
\hline
\end{tabular}


Considering a three-way interaction design for year $(\mathrm{Y})$, species $(\mathrm{S})$ and harvest time (HT) factors, $99 \%$ of combinations were statistically significant $(p<0.05)$. The analysis of variance designed with a two-way interaction design highlighted a significant effect of factor $\mathrm{Y}$ as main effect and/or in its interaction with $\mathrm{S}$ and HT, for all heavy metals considered in this experiment $(p<0.05)$, except $\mathrm{Zn}$. By pairwise comparisons among $Y$ levels on main and combined effects, significant differences were highlighted when comparing the first year with second and third years, for all heavy metals $(p<0.05)$, representing $81 \%$ of significant differences caused by this factor.

In almost all cases, metals were less accumulated in the biomasses of the first year than in the other two years, since the plants had not reached maturity.

Considering these results, the first year was excluded from the following calculations to consistently reduce type 2 errors in the analysis.

PCA analysis picked out $\mathrm{Zn}, \mathrm{Fe}$ and $\mathrm{Al}$ as the three most relevant components explaining almost all the variance among samples in the second and third years. The results highlighted that treatments were clustering by HT and S factors, whereas $\mathrm{Y}$ appeared to influence only the scattering within the clusters (Figure 3).

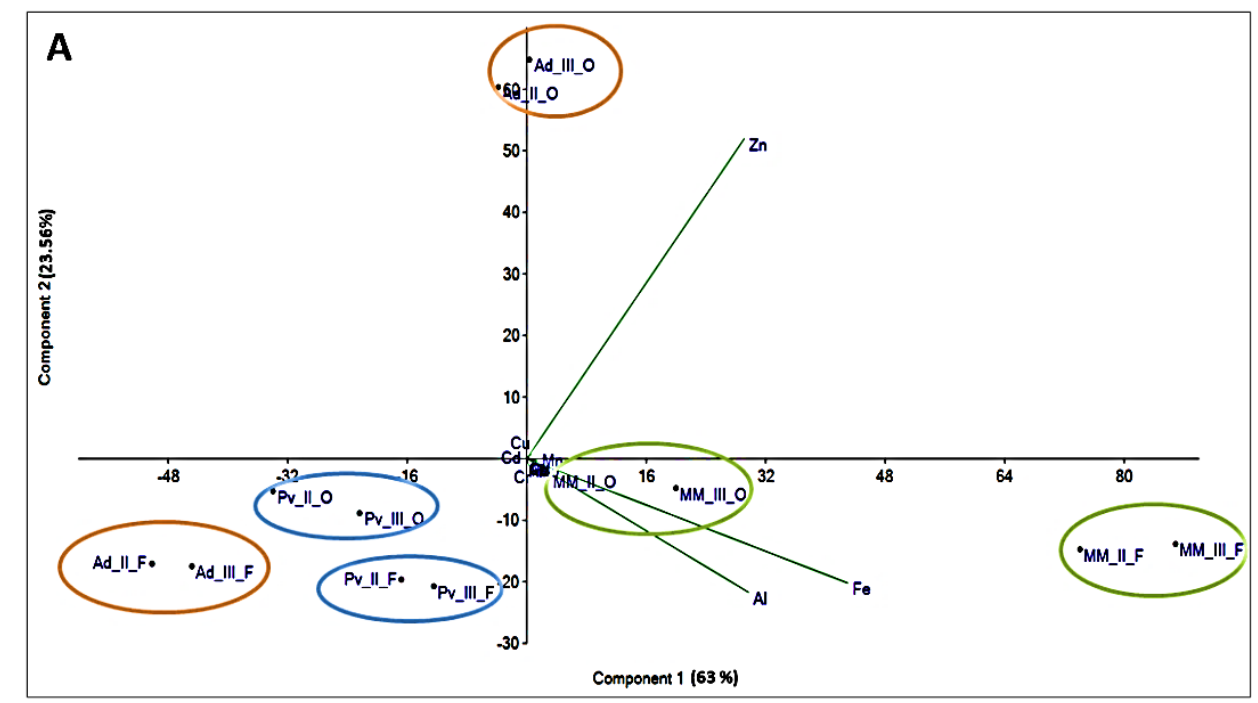

B

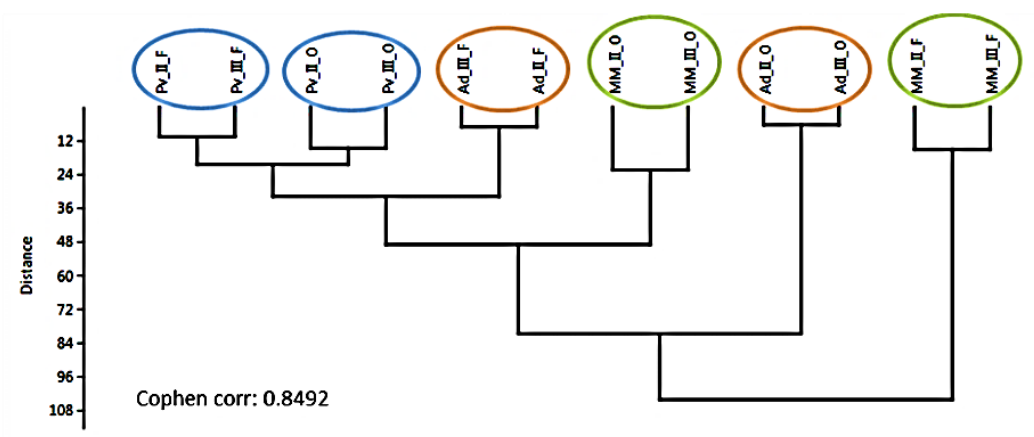

Figure 3. PCA biplot (A) and clustering analysis (B) based on the accumulation of 12 metals ( $\mathrm{Al}$, $\mathrm{Cr}, \mathrm{Mn}, \mathrm{Fe}, \mathrm{Co}, \mathrm{Ni}, \mathrm{Cu}, \mathrm{Zn}, \mathrm{As}, \mathrm{Mo}, \mathrm{Cd}$ and $\mathrm{Pb}$ ) in the biomass of $A$. donax $\mathrm{L}$. (Ad), switchgrass $(\mathrm{Pv})$ and mixed meadow (MM), considering the year of cultivation, second (_II) and third (_III), and the harvest time (October:_O and February:_F). In PCA analysis the first two axes (PC1 and PC2) explain $86.56 \%$ of the total variance. 
For the last two years of the experiments, the factor $\mathrm{Y}$ maintained an effect on heavy metals' uptake only for $\mathrm{Co}, \mathrm{As}, \mathrm{Cd}$ and $\mathrm{Pb}$ - elements sharing low accumulation in the harvested biomass, rarely exceeding $1 \mathrm{mg} / \mathrm{kg}^{-1}$ (Table 2). By multivariate analysis of variances, different effects were highlighted in the second and third years, with species (S) and harvest time (HT) factors and/or their interaction being significant $(p<0.05)$ for all metals excluding As and $\mathrm{Zn}$. Samples' contents of the 12 heavy metals are plotted in Figure 4 .

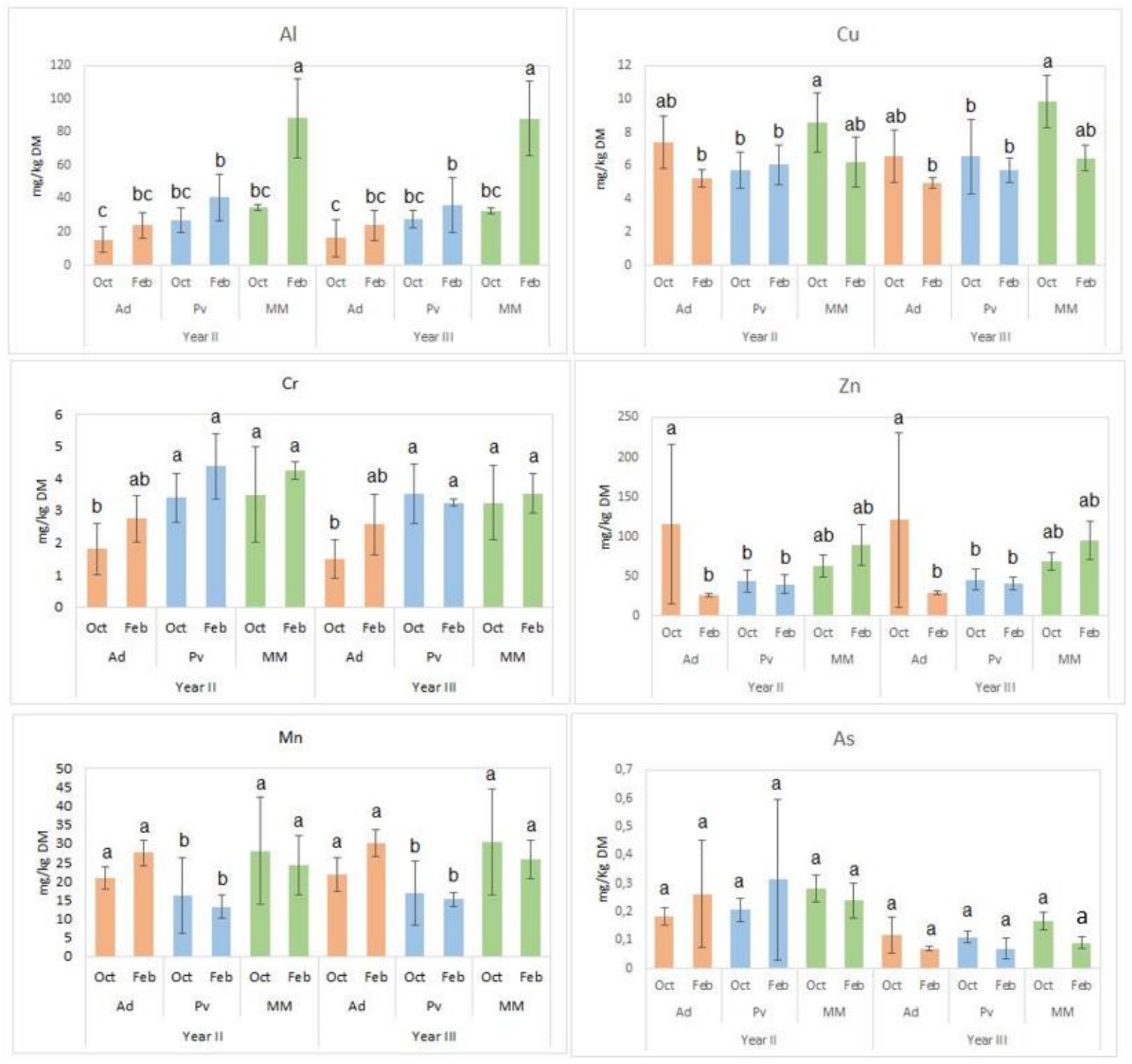

Figure 4. Cont. 


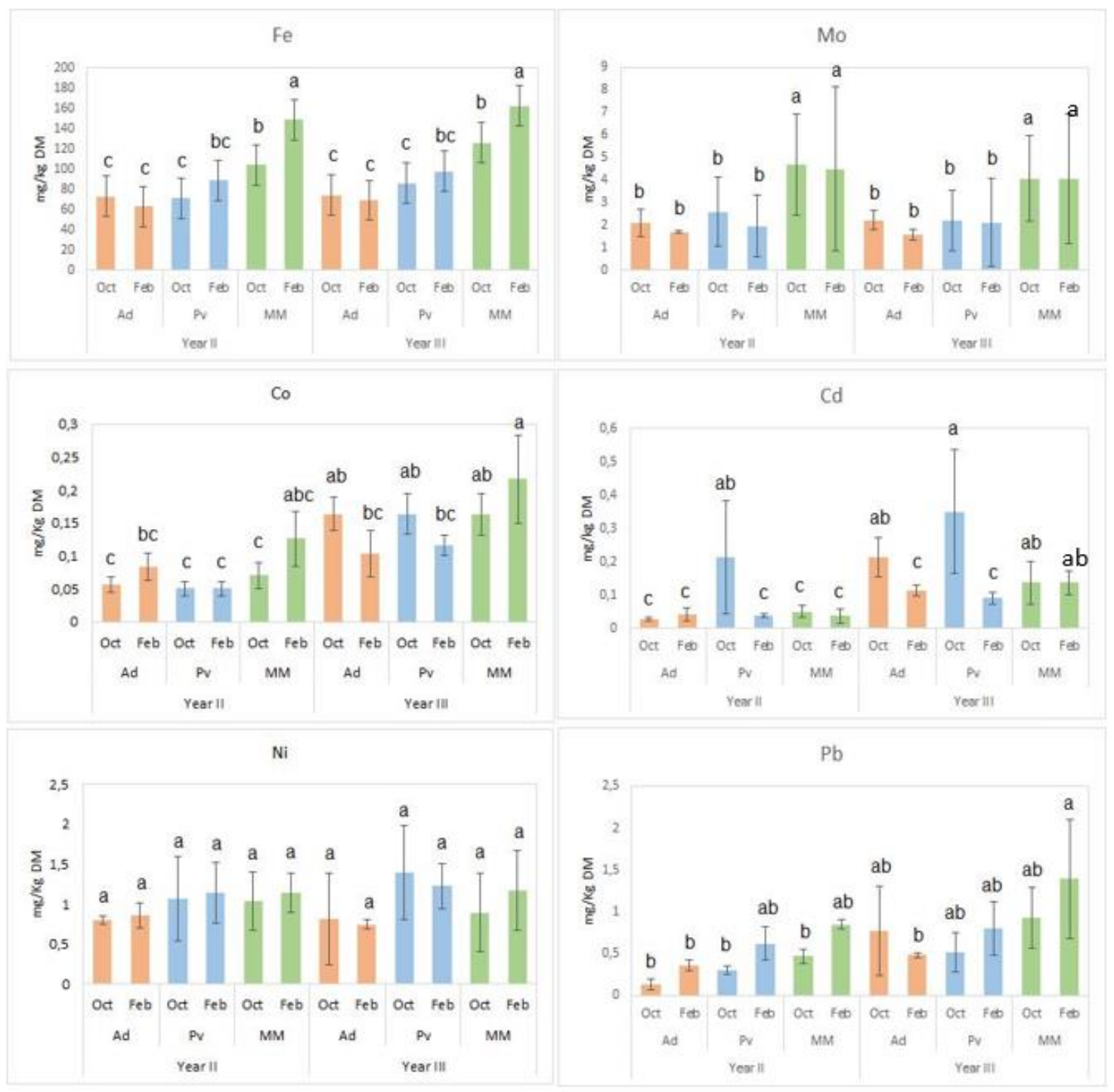

Figure 4. Accumulation of heavy metals in the harvested biomasses of the second and third years, separated into subgroups by Tukey HSD test. For Mn and Mo, groups were separated by species (S); for Al, Cr, Fe, Cu and Zn homogeneous groups were distinguished by species $(\mathrm{S})$ and harvest time (HT); for $\mathrm{Co}, \mathrm{Cd}$ and $\mathrm{Pb}$, groups considered $\mathrm{S}$, $\mathrm{HT}$ and year ( $\mathrm{Y})$ factors. Bars represent SD.

\subsection{Species and Harvest Time Effects}

The species factor $(\mathrm{S})$ effect was significant $(p<0.05)$ on harvested biomass accumulation for all heavy metals except Ni, $\mathrm{Zn}$ and As. A. donax L. (Ad) and switchgrass (Pv) had a similar accumulations of some heavy metals in the harvested biomasses, with $\mathrm{Al}, \mathrm{Fe}, \mathrm{Cu}$, $\mathrm{Mo}$ and $\mathrm{Pb}$ contents being lower than those of mixed meadows (MM). Considering $\mathrm{Cr}, \mathrm{Mn}$, $\mathrm{Ad}$ and $\mathrm{Pv}$, they were, respectively, lower than in MM. The effect of the harvest time factor (HT) was significant $(p<0.05)$ for $\mathrm{Al}, \mathrm{Cr}, \mathrm{Fe}, \mathrm{Cu}, \mathrm{Cd}$ and $\mathrm{Pb}$ harvested biomass uptake. The trend for $\mathrm{Al}, \mathrm{Cr}$ and $\mathrm{Fe}$ was for a higher content of heavy metal from the February harvest, whereas $\mathrm{Cu}, \mathrm{Cd}$ and $\mathrm{Zn}$ showed an opposite dynamic, with more accumulation for the October harvest. The two factors species (S) and harvest time (HT) had significant interactions $(p<0.05)$ for $\mathrm{Al}, \mathrm{Fe}, \mathrm{Co}, \mathrm{Zn}$ and $\mathrm{Cd}$, highlighting specific patterns of heavy metal accumulation. In particular, the control MM harvested in October accumulated more than two-fold the $\mathrm{Al}$ in comparison with other treatments. The same sampling was also favorable for Fe accumulation. For A. donax L., (Ad) accumulation of $\mathrm{Zn}$ was largely affected by HT, showing the highest and lowest results among samples for, respectively, October and February harvests. A similar effect of HT was highlighted for switchgrass (Pv) 
in $\mathrm{Cd}$ accumulation, with a more favorable HT in October. Considering the accumulation of Co, effects of year $(\mathrm{Y})$ with the factors $S$ and HT were significant: the control MM kept the same trend during the second and third years, whereas both Ad and Pv showed an overwinter increase of this element during the second year, but an overwinter reduction during the third year.

\subsection{Uptake Potential}

In Table 3 we report the amounts of heavy metals, expressed as $\mathrm{kg} \mathrm{ha}^{-1}$, that could be removed by phytoextraction in this polluted area, considering the third-year yield. In almost all cases A. donax, due to its high yield, was able to phytoextract higher amounts of heavy metals compared to switchgrass and mixed meadow. Furthermore, apart from Mn, $\mathrm{Cr}$ and $\mathrm{Al}$, the best harvest time to maximize the phytoextraction process turned out to be October, when the biomass harvested could be used in anaerobic digestion.

Table 3. Heavy metal uptake in the Caffaro area considering the yield from the third year of the experiment. Values are listed for A. donax L. (Ad), switchgrass (Pv) and mixed meadows (MM), for October (Oct) and February (Feb) harvests. Higher values are shown on a gray background.

\begin{tabular}{ccccccc}
\hline \multirow{2}{*}{ Heavy Metal } & \multicolumn{5}{c}{ Uptake in Third Year (kg ha-1) } \\
& Ad Oct & Ad Feb & Pv Oct & Pv Feb & MM Oct & MM Feb \\
\hline $\mathrm{Zn}$ & 3.87 & 0.99 & 0.84 & 0.80 & 0.91 & 1.14 \\
$\mathrm{Fe}$ & 2.37 & 2.39 & 1.57 & 1.96 & 1.68 & 1.96 \\
$\mathrm{Cu}$ & 2.09 & 1.7 & 0.12 & 0.11 & 0.13 & 0.08 \\
$\mathrm{Mn}$ & 0.69 & 1.04 & 0.31 & 0.30 & 0.41 & 0.31 \\
$\mathrm{Al}$ & 0.52 & 0.83 & 0.51 & 0.72 & 0.44 & 1.06 \\
$\mathrm{Mo}$ & 0.07 & 0.05 & 0.04 & 0.04 & 0.05 & 0.05 \\
$\mathrm{Cr}$ & 0.05 & 0.09 & 0.06 & 0.07 & 0.04 & 0.04 \\
$\mathrm{Ni}$ & 0.03 & 0.03 & 0.03 & 0.02 & 0.01 & 0.01 \\
$\mathrm{~Pb}$ & 0.02 & 0.02 & 0.01 & 0.02 & 0.01 & 0.02 \\
$\mathrm{Cd}$ & 0.007 & 0.004 & 0.006 & 0.002 & 0.002 & 0.002 \\
$\mathrm{Co}$ & 0.005 & 0.004 & 0.003 & 0.002 & 0.002 & 0.003 \\
$\mathrm{As}$ & 0.004 & 0.002 & 0.002 & 0.001 & 0.002 & 0.001 \\
\hline
\end{tabular}

\section{Discussion}

Giant reed, considered for many years only as a weed, is now considered as an energy crop that can be used in marginal areas that cannot be used by conventional agriculture $[2,38]$.

Due to anthropic activities, marginal lands are increasing worldwide mainly because of salinization caused by irrigation [39] and heavy metal contamination caused by industrial activities [40]. This could mean more opportunities to cultivate energy crops which are environmentally friendly, such as giant reed crops, in the near future.

The consideration of novel strategies for the sustainable use of marginal lands in Mediterranean areas was the aim of the European project, OPTIMA (Optimization of Perennial Grasses for Biomass Production in the Mediterranean Area) [41]. In this framework, considering four perennial species, cardoon, giant reed, miscanthus and switchgrass, the OPTIMA project highlighted giant reed when compared to the other energy crops $[42,43]$.

Furthermore, deep-rooted perennial grasses such as giant reed (Arundo donax L.) and switchgrass (Panicum virgatum L.) can provide a contribution to the reduction of greenhouse-gas emissions [44,45], producing biomass to displace fossil fuels [46] and for the phytoremediation of polluted soils.

In our study, $A$. donax, switchgrass and mixed meadow biomasses produced in a polluted area in northern Italy were compared for two harvest times (October and February) in a three year experiment, with the aim of assessing the capacity of phytoextraction of the heavy metals and the best outcome for energy production (mainly anaerobic digestion and combustion) (Figure 1). This research started from the results of project LUCAS's topsoil 
survey, which built a consistent spatial database of polluted soil across Europe. In this project it was estimated that $137,000 \mathrm{~km}^{2}$ needs local assessment and eventual remediation action [47].

Giant reed biomass has found wide applications in energy production; it can be used in combustion, gasification and pyrolysis and to produce biogas [1]. In fact, when harvested in autumn its biomass can be used in anaerobic digestion in substitution/partial integration with the traditional energy crops [48-50], and the biomass harvested in winter can be used for the combustion process, due to its high heating value of about $18.7 \mathrm{MJ} \mathrm{kg}^{-1}$ [1].

The estimated yields for Arundo and switchgrass in the third year, obtained in this work, reported in Figure 2, (respectively, about 33 and 19 tons ha $^{-1}$ ), substantially confirm the data present in the literature where A. donax in the Mediterranean basin is the most productive energy crop [1,51-53]. We decided not to consider the data obtained in the first year of experimentation-although it is reported in Table 2-given that in the first year of planting both Arundo and switchgrass were not in full production and had not fully developed either their rhizomes or the root systems. This decision was supported by pairwise comparisons among $\mathrm{Y}$ levels on main and combined effects, where significant differences were observed when comparing the first year with second and third years, for all heavy metals accumulated. In fact, when considering the data reported in Figure 3, concerning the biplot PCA and clustering analysis obtained for the 12 heavy metals considered in this study, the same accumulation pattern was found in the second and third years.

The results shown in Table 2 and Figure 4, regarding the accumulation of heavy metals in the biomasses of the three different species, are in agreement with previous work reporting the bioaccumulation factor $(\mathrm{BAF}=\mathrm{C}$ plant $/ \mathrm{C}$ soil) considering only the biomass harvested of Ad [54], Pv [55] and MM [56].

The highest value of phytoextraction was found for $\mathrm{Zn}$ (Figure 4). $\mathrm{Zn}$ is an essential micronutrient for plant growth; hence, it is not surprising that it was present in the harvested biomass in higher concentrations in comparison to the other heavy metals such as $\mathrm{Cu}, \mathrm{Co}, \mathrm{Fe}, \mathrm{Ni}, \mathrm{Mn}$ and $\mathrm{Mo}$ that can also be removed from soils via phytoextraction [57]. For the heavy metals that lack a known biological function ( $\mathrm{Al}, \mathrm{Cr}, \mathrm{Cd}$ and $\mathrm{Pb}$ ), but represent an important environmental issue, significant uptake has been reported [58-60]. The metals accumulated in plant biomass reflect the metal contents present in the soil. Each species has its own accumulation profile (we could say a chemical barcoding or chemotype) as shown in the PCA (Figure 3), where the analyses of the various biomasses cluster by species (Ad, Pv and MM), year (II and III) and harvest period (October and February). One of the main factors that can explain the differences observed among different species lies in the different capacities that plants have to release organic compounds (e.g., chelators) via root apparatus capable of modifying the rhizosphere and the $\mathrm{pH}$ of the soil. Of course, these chemical changes affecting the soil around the root system increase the solubility of metals [61]. Another aspect to take into consideration lies in the different physiology of the plants under study: Ad and Pv are monocotyledons, whereas MM consisted mainly of two dicotyledonous species (Medicago sativa and Chenopodium album). Furthermore, Ad and Pv are rhizomatous plants, but the rhizomatous apparatus of arundo is much larger, and Pv is able to produce seeds, as is MM [62]. Hence, by taking together all these different characteristics, we can hypothesize, starting from the results reported in Figure 3, that: (i) In the case of Ad, the difference in the metals accumulated between the biomass collected in February and October can be explained by the translocation of the nutrients present in the epigeal part of the plant towards the rhizomes (statistically significant difference in the case of $\mathrm{Zn}$, Figure 4). (ii) In the case of Pv there are no major differences between the two types of biomass (harvested in October and February) probably due to the small rhizomatous apparatus, unable to translocate large quantities of nutrients. However, one statistically significant difference was observed in the case of $\mathrm{Cd}$, of which more wasaccumulated in the biomass collected in October (Figure 4). In this case we can hypothesize that the $\mathrm{Cd}$ accumulated in the seeds still present on the plant in October was lost in February 
where the seeds would have fallen to the ground. The fact is well known that $\mathrm{Cd}$ is accumulated in plant seeds, representing a big issue for agriculture conducted on soils polluted by this metal [63]. (iii) For what concerns MM, the explanation regarding the differences observed for the metals accumulated in the two different harvest times could be more complex since it is a polyphite crop. However, the biggest difference was observed regarding $\mathrm{Al}$ (difference statistically significant reported in Figure 4). Al toxicity is one of the major limiting factors for crop production on arable lands [64].We can hypothesize that the higher level of $\mathrm{Al}$ observed in the biomass harvested in February may have been due to accumulation in the plant cell wall of the tiny stems present in $\mathrm{MM}$; in fact, $\mathrm{Al}$ is able to displace $\mathrm{Ca}^{2+}$ in the cell wall [65].

Table 3 shows the amounts of heavy metals removed by phytoextraction in this polluted area, considering the third-year yield. Due to the higher yield of $A$. donax in almost all cases ( $\mathrm{Zn}, \mathrm{Fe}, \mathrm{Cu}, \mathrm{Mn}, \mathrm{Mo}, \mathrm{Cr}, \mathrm{Ni}, \mathrm{Pb}, \mathrm{Cd}, \mathrm{Co}$ and $\mathrm{As}$ ) the utilization of this species allowed the removal of the greatest quantity of heavy metals compared to the crops $\mathrm{Pv}$ and MM. Only in the case of $\mathrm{Al}$ did the MM record a better value (1.06 vs. $0.83 \mathrm{k} / \mathrm{ha}^{-1}$ ). Al toxicity is one of the major limitations for crop yields on acid soils, which occur in up to $30-40 \%$ of the arable lands of the world: $\mathrm{Al}$ is toxic to plants such as maize, barley and wheat, when solubilized into the soil solution at acidic $\mathrm{pH}$ values [66]. However, the difference in the $\mathrm{Al}$ removal between $\mathrm{MM}$ and $\mathrm{Ad}$ is not so great ( 0.83 vs. $1.06 \mathrm{~kg} \mathrm{ha}^{-1}$ year $^{-1}$ ) as to justify the preferential use of MM, with which the biomass produced would be difficult to manage and not usable for producing energy. Furthermore, apart from $\mathrm{Al}, \mathrm{Mn}$ and $\mathrm{Cr}$, the better harvest time to maximize the phytoextraction of $\mathrm{Zn}$, $\mathrm{Fe}, \mathrm{Cu}, \mathrm{Mo}, \mathrm{Ni}, \mathrm{Pb}, \mathrm{Cd}, \mathrm{Co}$ and As was in October, when the biomass harvested could be used in anaerobic digestion, a well established technology in Lombardy.

Animal production, in particular pig farms, represents a possible source of heavy metals. In fact, the major input in pig livestock is represented by feed, which should be controlled in order to prevent the excessive spread of heavy metals into the environment $[35,67,68]$. On the other hand, minerals such as $\mathrm{Co}, \mathrm{Cu}, \mathrm{Fe}, \mathrm{Mn}$, Mo and $\mathrm{Zn}$ are important cofactors for various enzymatic activities and consequently should be used to supplement animals' diet in accordance with the authorized levels [69].

Furthermore, $\mathrm{Zn}$ in particular is usually used to guarantee livestock productivity by controlling bacterial pathogen infections [70]. After the antibiotics ban in 2006 in Europe [58], there has been an increased use of high dosages of zinc oxide (ZnO). However, excessive exposure with higher concentrations of $\mathrm{Zn}$ has been linked to environmental issues; hence. the EU has now banned the inclusion of pharmacological levels of $\mathrm{ZnO}$ after 2022 [71].

\section{Conclusions}

In this work we reported the results concerning three years of trials regarding the cultivation of $A$. donax, switchgrass and mixed meadow in the polluted Caffaro area. The results obtained showed that A. donax is the best choice for phytoextraction and energy production due to the higher yield. In particular, considering the uptake of heavy metals in the third year of the experiment, $A$. donax is able to accumulate in its harvested biomass considerable amounts of $\mathrm{Zn}$ and $\mathrm{Cu}$ (3.87 and $2.09 \mathrm{~kg} / \mathrm{ha}$ respectively). Hence, this species could become an excellent solution for phytoremediation of soils contaminated by heavy metals [72] while at the same time producing energy. Considering the serious problems within northern Italy, concerning in particular $\mathrm{Cu}$, used as an anti-cryptogrammic, $\mathrm{Zn}$, used extensively in pig farms and Cd, introduced with phosphate-based fertilizers, this crop could be strategic for the sustainability of agricultural supply chains.

Author Contributions: Conceptualization, R.P. and F.A.; methodology, R.P. and T.D.; software, T.D. formal analysis, T.D. and E.C.; data curation, S.S., S.A., G.M., A.S. and F.C.; writing-original draft preparation, T.D.; writing-review and editing, R.P. and F.A.; supervision, R.P.; funding acquisition, R.P. and F.A. All authors have read and agreed to the published version of the manuscript. 
Funding: This research received no external funding.

Institutional Review Board Statement: Not applicable.

Informed Consent Statement: Not applicable.

Data Availability Statement: No data.

Acknowledgments: We wish to thank Andrea Scapin for his hard work in the field and Lesley Currah for her editing and suggestions.

Conflicts of Interest: The authors declare no conflict of interest.

\section{References}

1. Corno, L.; Pilu, R.; Adani, F. Arundo donax L.: A non-food crop for bioenergy and bio-compound production. Biotechnol. Adv. 2014, 32, 1535-1549. [CrossRef] [PubMed]

2. Di Nasso, N.; Roncucci, N.; Bonari, E. Seasonal dynamics of aboveground and belowground biomass and nutrient accumulation and remobilization in giant reed (Arundo donax L.): A three-year study on marginal land. Bioenergy Res. 2013, 6, 725-736. [CrossRef]

3. Basso, M.C.; Cerrella, E.G.; Buonomo, E.L.; Bonelli, P.R.; Cukierman, A.L. Thermochemical Conversion of Arundo Donax into Useful Solid Products. Energy Sources 2005, 27, 1429-1438. [CrossRef]

4. Jeguirim, M.; Trouvé, G. Pyrolysis characteristics and kinetics of Arundo donax using thermogravimetric analysis. Bioresour. Technol. 2009, 100, 4026-4031. [CrossRef]

5. Bezzi, G.; Monti, A.; Venturi, G. Colture da energia: Tecniche di coltivazione e gestione economica. Agricoltura 2006, 6, 24-30.

6. Nurek, T.; Gendek, A.; Roman, K. Forest Residues as a Renewable Source of Energy: Elemental Composition and Physical Properties. Bioresources 2019, 14, 6-20. [CrossRef]

7. Dahl, J.; Obernberger, I. Evaluation of the combustion characteristics of four perennial energy crops (Arundo donax, Cynara cardanculus, Miscanthus x Giganteus and Panicum virgatum). In Proceedings of the 2nd World Conference on Biomass for Energy, Industry and Climate Protection, Rome, Italy, 10-14 May 2004.

8. Koppolu, L.; Agblevor, F.A.; Clements, L.D. Pyrolysis as a technique for separating heavy metals from hyperaccumulators. Biomass Bioenergy 2003, 25, 651-663. [CrossRef]

9. Coyne, M.S. Soil Microbiology: An Exploratory Approach; Lab Manual; Delmar: New York, NY, USA, 1999.

10. Kelly, J.J.; Tate, R.L. Effects of heavy metals contamination and remediation on soil microbial communities in the vicinity of a Zn smelter. J. Environ. Qual. 1998, 27, 609-617. [CrossRef]

11. Bhogal, A.; Nicholson, F.A.; Chambers, B.J.; Shepherd, M.A. Effects of past sewage sludge additions on heavy metal availability in light textured soils: Implications for crop yields and metal uptakes. Environ. Pollut. 2003, 121, 413-423. [CrossRef]

12. Granato, T.C.; Pietz, R.I.; Knafl, G.J.; Carlson, C.R., Jr.; Tata, P.; Lue-Hing, C. Trace element concentrations in soils, corn leaves, and grain after cessation of biosolids application. J. Environ. Qual. 2004, 33, 2078-2089. [CrossRef]

13. Legambiente, 2014. Available online: http://www.legambiente.it/contenuti/comunicati/legambiente-presenta-il-dossierbonifiche-dei-siti-inquinati-chimera-o-realta (accessed on 12 September 2020).

14. Peralta-Videa, J.R.; Lopez, M.L.; Narayan, M.; Saupea, G.; Gardea-Torresdey, J. The biochemistry of environmental heavy metal uptake by plants: Implications for the food chain. Int. J. Biochem. Cell Biol. 2009, 41, 1665-1677. [CrossRef] [PubMed]

15. McCutcheon, S.C.; Schnoor, J.L. Phytoremediation: Transformation and Control of Contaminants; John Wiley \& Sons: Hoboken, NJ, USA, 2003; Volume 121.

16. Singer, A.; Mackova, M.; Dowling, D.N.; Macek, T. Phytoremediation and Rhizoremediation; Theoretical Background; Springer Science \& Business Media: Berlin/Heidelberg, Germany, 2006; Volume 9.

17. Salt, D.E.; Blaylock, M.; Nanda Kumar, P.B.A.; Dushenkov, V.; Ensley, B.D.; Raskin, I. Phytoremediation: A novel strategy for the removal of toxic metals from the environment using plants. Biotechnology 1995, 13, 468-474. [CrossRef] [PubMed]

18. Brooks, R.R. Plants and Chemical Elements: Biochemistry, Uptake, Tolerance and Toxicity; Gargo, M.E., Ed.; VCH Verlagsgesellsschaft: Weinheim, Germany, 1994.

19. Yang, X.E.; Long, X.X.; Ni, W.Z.; Fu, C.X. Sedum alfredii H: A new Zn hyperaccumulating plant first found in China. China Sci. Bull. 2002, 47, 1634-1637. [CrossRef]

20. Brooks, R.R.; Chambers, M.F.; Nicks, L.J.; Robinson, B.H. Phytomining. Trends Plant Sci. 1998, 1, 359-362. [CrossRef]

21. Kacálková, L.; Tlustoš, P.; Száková, J. Phytoextraction of cadmium, copper, zinc and mercury by selected plants. Plant Soil Environ. 2009, 55, 295-304. [CrossRef]

22. Vigil, M.; Marey-Pérez, M.F.; Huerta, G.M.; Cabal, V.Á. Is phytoremediation without biomass valorization sustainable? Comparative LCA of landfilling vs. anaerobic co-digestion. Sci. Total Environ. 2015, 505, 844-850. [CrossRef]

23. Mirza, N.; Pervez, A.; Mahmood, Q.; Shah, M.M.; Shafqat, M.N. Ecological restoration of arsenic contaminated soil by Arundo donax L. Ecol. Eng. 2011, 37, 1949-1956. [CrossRef]

24. Ammari, T.G. Utilization of a natural ecosystem bio-waste; leaves of Arundo donax reed, as a raw material of low-cost ecobiosorbent for cadmium removal from aqueous phase. Ecol. Eng. 2014, 71, 466-473. [CrossRef] 
25. Dupuy, J.; Ouvrard, S.; Leglize, P.; Sterckeman, T. Morphological and physiological responses of maize (Zea mays) exposed to sand contaminated by phenanthrene. Chemosphere 2015, 124, 110-115. [CrossRef]

26. Jeong, S.; Moon, H.S.; Nam, K. Increased ecological risk due to the hyperaccumulation of As in Pteris cretica during the phytoremediation of an As-contaminated site. Chemosphere 2015, 122, 1-7. [CrossRef]

27. Maestri, E.; Marmiroli, M.; Visioli, G.; Marmiroli, N. Metal tolerance and hyperaccumulation: Costs and trade-offs between traits and environment. Environ. Exp. Bot. 2010, 68, 1-13. [CrossRef]

28. Guo, Z.H.; Miao, X.F. Growth changes and tissues anatomical characteristics of giant reed (Arundo donax L.) in soil contaminated with arsenic, cadmium and lead. J. Cent. South Univ. 2010, 17, 770-777. [CrossRef]

29. Han, Z.; Hu, Z. Tolerance of Arundo donax to heavy metals. Chin. J. Appl. Ecol. 2005, 16, 161-165.

30. Sabeen, M.; Mahmood, Q.; Irshad, M.; Fareed, I.; Khan, A.; Ullah, F.; Hussain, J.; Hayat, Y.; Tabassum, S. Cadmium phytoremediation by Arundo donax L. from contaminated soil and water. BioMed Res. Int. 2013. [CrossRef] [PubMed]

31. Pilu, R.; Cassani, E.; Landoni, M.; Badone, F.C.; Passera, A.; Cantaluppi, E.; Corno, L.; Adani, F. Genetic characterization of an Italian Giant Reed (Arundo donax L.) clones collection: Exploiting clonal selection. Euphytica 2014, 196, 169-181. [CrossRef]

32. Danelli, T.; Cantaluppi, E.; Tosca, A.; Cassani, E.; Landoni, M.; Bosio, S.; Adani, F.; Pilu, R. Influence of clonal variation on the efficiency of Arundo donax propagation methods. J. Plant Growth Regul. 2019, 38, 1449-1457. [CrossRef]

33. Danelli, T.; Laura, M.; Savona, M.; Landoni, M.; Adani, F.; Pilu, R. Genetic improvement of Arundo donax L.: Opportunities and challenges. Plants 2020, 9, 1584. [CrossRef]

34. Decreto Legislativo 3 aprile 2006, n. 152. "Norme in materia ambientale". G.U. n. 88 del. 14/04/2006-S.O. n. 96

35. Hejna, M.; Moscatelli, A.; Stroppa, N.; Onelli, E.; Pilu, S.; Baldi, A.; Rossi, L. Bioaccumulation of heavy metals from wastewater through a Typha latifolia and Thelypteris palustris phytoremediation system. Chemosphere 2020, 241. [CrossRef]

36. IBM Corp. IBM SPSS Statistics for Windows, Version 27.0; IBM Corp.: Armonk, NY, USA, 2020.

37. Hammer, Ø.; Harper, D.A.T.; Ryan, P.D. PAST: Paleontological statistics software package for education and data analysis. Paleontol. Electron. 2001, 4.

38. Nackley, L.L.; Kim, S.H. [A salt] on the bioenergy and biological invasions debate: Salinity tolerance of the invasive biomass feed stock Arundo donax. GCB Bioenergy 2014, 7, 752-762. [CrossRef]

39. Mayak, S.; Tirosh, T.; Glick, B.R. Plant growth-promoting bacteria confer resistance in tomato plants to salt stress. Plant Physiol. Biochem. 2004, 42, 565-572. [CrossRef] [PubMed]

40. Tóth, G.; Hermann, T.; da Silva, M.; Montanarella, L. Heavy metals in agricultural soils of the European Union with implications for food safety. Environ. Int. 2016, 88, 299-309. [CrossRef] [PubMed]

41. Monti, A.; Cosentino, S.L. Conclusive results of the European Project OPTIMA: Optimization of perennial grasses for biomass production in the Mediterranean area. Bioenergy Res. 2015, 8, 1459-1460. [CrossRef]

42. Fernando, A.L.; Boléo, S.; Barbosa, B.; Costa, J.; Duarte, M.P.; Monti, A. Perennial grass production opportunities on marginal Mediterranean land. Bioenergy Res. 2015, 8, 1523-1537. [CrossRef]

43. Corno, L.; Pilu, R.; Cantaluppi, E.; Adani, F. Giant cane (Arundo donax L.) for biogas production: The effect of two ensilage methods on biomass characteristics and biogas potential. Biomass Bioenergy 2016, 93, 131-136. [CrossRef]

44. Lemus, R.; Lal, R. Bioenergy crops and carbon sequestration. Crit. Rev. Plant Sci. 2007, 24, 1-21. [CrossRef]

45. Agostini, F.; Gregory, A.S.; Richter, G.M. Carbon sequestration by perennial energy crops: Is the jury still out? Bioenergy Res. 2015, 8, 1057-1080. [CrossRef]

46. Schmidt, T.; Fernando, A.L.; Monti, A.; Rettenmaier, N. Life cycle assessment of bioenergy and bio-based products from perennial grasses cultivated on marginal land in the Mediterranean region. Bioenergy Res. 2015, 8, 1548-1561. [CrossRef]

47. Fernández-Ugalde, O.; Ballabio, C.; Lugato, E.; Scarpa, S.; Jones, A. Assessment of Changes in Topsoil Properties in LUCAS Samples between 2009/2012 and 2015 Surveys, EUR 30147 EN; Publications Office of the European Union: Luxembourg, 2020; ISBN 978-92-76-17430-1. [CrossRef]

48. Luca, C.; Pilu, R.; Tambone, F.; Scaglia, B.; Adani, F. New energy crop giant cane (Arundo donax L.) can substitute traditional energy crops increasing biogas yield and reducing costs. Bioresour. Technol. 2015, 191, 197-204.

49. Corno, L.; Lonati, S.; Riva, C.; Pilu, R.; Adani, F. Giant cane (Arundo donax L.) can substitute traditional energy crops in producing energy by anaerobic digestion, reducing surface area and costs: A full-scale approach. Bioresour. Technol. 2016, 218, 826-832. [CrossRef]

50. Ceotto, E.; Vasmara, C.; Marchetti, R.; Cianchetta, S.; Galletti, S. Biomass and methane yield of giant reed (Arundo donax L.) as affected by single and double annual harvest. Glob. Chang. Biol. Bioenergy 2021, 1-15. [CrossRef]

51. Monti, A.; Zegada-Lizarazu, W. Sixteen-year biomass yield and soil carbon storage of giant reed (Arundo donax L.) grown under variable nitrogen fertilization rates. Bioenergy Res. 2016, 9, 248-256. [CrossRef]

52. Piscioneri, I.; Pignatelli, V.; Palazzo, S.; Sharma, N. Switchgrass production and establishment in the Southern Italy climatic conditions. Energy Convers. Manag. 2001, 42, 2071-2082. [CrossRef]

53. Angelini, L.G.; Ceccarini, L.; Di Nasso, N.N.; Bonari, E. Comparison of Arundo donax L. and Miscanthus x giganteus in a long-term field experiment in Central Italy: Analysis of productive characteristics and energy balance. Biomass Bioenergy 2009, 33, 635-643. [CrossRef] 
54. Barbosa, B.; Boléo, S.; Sidella, S.; Costa, J.; Duarte, M.P.; Mendes, B.; Cosentino, S.L.; Fernando, A.L. Phytoremediation of heavy metal-contaminated soils using the perennial energy crops Miscanthus spp. and Arundo donax L. Bioenergy Res. 2015, 8 , 1500-1511. [CrossRef]

55. Shrestha, P.; Bellitürk, K.; Görres, J.H. Phytoremediation of heavy metal-contaminated soil by switchgrass: A comparative study utilizing different composts and coir fiber on pollution remediation, plant productivity, and nutrient leaching. Int. J. Environ. Res. Public Health 2019, 16, 1261. [CrossRef]

56. Yun, L.; Jensen, K.B.; Larson, S.R.; Waldron, B.L. Uptake of As, Cd, Cu, Fe, Mn, Pb, and $\mathrm{Zn}$ in pasture grasses on three metal contaminated soils from Montana. J. Agric. Sci. Bot. 2018, 2, 34-40. [CrossRef]

57. Tangahu, B.V.; Sheikh Abdullah, S.R.; Basri, H.; Idris, M.; Anuar, N.; Mukhlisin, M. A review on heavy metals (As, Pb, and Hg) uptake by plants through phytoremediation. Int. J. Chem. Eng. 2011, 2011. [CrossRef]

58. Gutser, R.; Ebertseder, T.; Weber, A.; Schraml, M.; Schmidhalter, U. Short-term and residual availability of nitrogen after long-term application of organic fertilizers on arable land. J. Plant Nutr. Soil Sci. 2005, 168, 439-446. [CrossRef]

59. Gaur, A.; Adholeya, A. Prospects of arbuscular mycorrhizal fungi in phytoremediation of heavy metal contaminated soils. Curr. Sci. 2004, 86, 528-534.

60. Shahandeh, H.; Hossner, L.R. Plant screening for chromium phytoremediation. Int. J. Phytoremediat. 2000, 2, 31-51. [CrossRef]

61. Chang, C.; Janzen, H.H. Long-term fate of nitrogen from annual feedlot manure applications. J. Environ. Qual. 1996, 25, 785-790. [CrossRef]

62. Lewandowski, I.; Scurlock, J.M.; Lindvall, E.; Christou, M. The development and current status of perennial rhizomatous grasses as energy crops in the US and Europe. Biomass Bioenergy 2003, 25, 335-361. [CrossRef]

63. Huybrechts, M.; Cuypers, A.; Deckers, J.; Iven, V.; Vandionant, S.; Jozefczak, M.; Hendrix, S. Cadmium and Plant Development: An Agony from Seed to Seed. Int. J. Mol. Sci. 2019, 20, 3971. [CrossRef]

64. Kochian, L.V.; Piñeros, M.A.; Hoekenga, O.A. The physiology, genetics and molecular biology of plant aluminum resistance and toxicity. Plant Soil 2005, 274, 175-195. [CrossRef]

65. Blamey, F.C.P.; Dowling, A.J. Antagonism between aluminium and calcium for sorption by calcium pectate. Plant Soil 1995, 171, 137-140. [CrossRef]

66. Kochian, L.V. Cellular mechanism of aluminium toxicity and resistance in plants. Annu. Rev. Plant Physiol. Plant Mol. Biol. 1995, 46, 237-260. [CrossRef]

67. Hejna, M.; Moscatelli, A.; Onelli, E.; Baldi, A.; Pilu, S.; Rossi, L. Evaluation of concentration of heavy metals in animal rearing system. Ital. J. Anim. Sci. 2019, 18, 1372-1384. [CrossRef]

68. Adewole, D.I.; Kim, I.H.; Nyachoti, C.M. Gut health of pigs: Challenge models and response criteria with a critical analysis of the effectiveness of selected feed additives-A review. Asian Australas. J. Anim. Sci. 2016, 29, 909-924. [CrossRef]

69. European Parliament and the Council. Regulation (EC) no 1831/2003 of 22 September 2003 on additives for use in animal nutrition. Off. J. Eur. Union 2003, 50, 29-43.

70. Liu, Y.; Espinosa, C.D.; Abelilla, J.J.; Casas, G.A.; Lagos, L.V.; Lee, S.A.; Kwon, W.B.; Mathai, J.K.; Navarro, D.; Jaworski, N.W.; et al. Non-antibiotic feed additives in diets for pigs: A review. Anim. Nutr. 2018, 4, 113-125. [CrossRef] [PubMed]

71. European Medicine Agency. European Medicine Agency (EMA) N 394961/2017. Questions and Answers on Veterinary Medicinal Products Containing Zinc Oxide to Be Administered Orally to Foodproducing Species; European Medicine Agency: Amsterdam, The Netherlands, 2017.

72. Cristaldi, A.; Oliveri Conti, G.; Cosentino, S.L.; Mauromicale, G.; Copat, C.; Grasso, A.; Zuccarello, P.; Fiore, M.; Restuccia, C.; Ferrante, M. Phytoremediation potential of Arundo donax (Giant Reed) in contaminated soil by heavy metals. Environ. Res. 2020, 185, 109427. [CrossRef] [PubMed] 